\title{
Prevalence of the Palmaris Longus and its Impact on Grip Strength in Elite Gymnasts and Non-Athletes
}

\author{
Prevalencia del Músculo Palmar Largo y el Impacto en la \\ Fuerza de Agarre en Gimnastas de Elite y No Atletas
}

\author{
Mirela Eric ${ }^{1}$; Kaissar Yammine ${ }^{2,3}$; Goran Vasic ${ }^{4}$; Mirjana Dejanovic ${ }^{5}$ \& Dea Karaba Jakovljevic ${ }^{6}$
}

ERIC, M.; YAMMINE, K.; VASIC, G.; DEJANOVIC, M. \& KARABA JAKOVLJEVIC, D. Prevalence of the palmaris longus and its impact on grip strength in elite gymnasts and non-athletes. Int. J. Morphol., 37(4):1361-1369, 2019.

SUMMARY: In elite athletes, the palmaris longus (PL) presence has a potential contribution to hand strength, smaller reaction time, better shooting speed and power. The aim of this study was to investigate the prevalence of PL in elite competitive artistic gymnasts and its impact on grip strength compared to a control group of moderately active non-athletes. This prospective study included 370 subjects divided in two groups (170 elite artistic gymnasts and 200 moderately active non-athletes, students of medicine). The study consisted of two clinical sets of examination: a search for the clinical presence of PL was initially conducted followed by the assessment of maximal grip strength. Standard and six additional tests were performed to confirm PL tendon absence. Maximal grip strength was measured bilaterally with an electronic hand dynamometer. Bilateral absence was more common than unilateral, predominately noted on left side in both study groups. Unilateral PL absence was correlated to decreased grip strength in students, while the opposite was found in gymnasts. The mean value of grip strength in some age groups was higher on the side where the PL was absent. The results of our study show that the presence of the PL doesn`t affect the hand grip strength in gymnasts. Due to the low incidence of unilateral PL absence, further large-sampled research is warranted to assess PL contribution to hand grip strength and to other hand functions that could be of significant importance for athletes and non-athletes.

KEY WORDS: Palmaris longus muscle; Prevalence; Hand grip strength; Elite athletes; Gymnasts.

\section{INTRODUCTION}

Palmaris longus (PL) is one of the most variable muscles in the human body (Tubbs et al., 2016) and the most studied in clinical anatomy (Gangata, 2009; Kose et al., 2009; Eric et al., 2010; Kyung et al., 2012; Snell, 2012; Abdolahzadeh Lahiji et al., 2013; Raouf et al., 2013; Standring, 2016). The overall clinical absence of PL has been reported to be $20.25 \%$ (Yammine, 2013), higher than the $15 \%$ usually stated in standard textbooks (Saldana, 1996; Smith, 2002; Snell). The frequency of PL absence has been shown to present wide variations, mostly in relation to ethnicity (Yammine). The variation has been reported to range between $0.6 \%$ in Korean population to $63.9 \%$ in Turkish population (Ceyhan \& Mavt, 1997; Ahn et al., 2000).
The meta-analysis of Yammine showed no statistically differences of prevalence values between unilateral and bilateral presence, and between females and males. However and in discordance with the literature, PLA was statistically more predominant on the right side.

Besides being of high clinical practice where it is often used as a tendon graft for reconstructive hand surgery (Kleinert et al., 1991), its function as a flexor of the wrist has been usually defined as minor (Verdan \& Poulenas, 1975; Sebastin et al., 2005; Karahan et al., 2017). Nevertheless, this statement has been challenged by many when PL contribution was assessed in professional sport players

\footnotetext{
${ }^{1}$ Department of Anatomy, Faculty of Medicine, University of Novi Sad, Serbia.

${ }^{2}$ Department of Orthopedic Surgery, Lebanese American University Medical Center-Rizk. School of Medicine, Beirut, Lebanon.

${ }^{3}$ Center for Evidence-based Anatomy, Sports and Orthopedic Research, Beirut, Lebanon.

${ }^{4}$ Faculty of Sport and Physical Education, University of Novi Sad, Serbia.

${ }^{5}$ Department of Physiology, Faculty of Medicine, University of Kosovska Mitrovica, Serbia.

${ }^{6}$ Department of Physiology, Faculty of Medicine, University of Novi Sad, Serbia.
} 
ERIC, M.; YAMMINE, K.; VASIC, G.; DEJANOVIC, M. \& KARABA JAKOVLJEVIC, D. Prevalence of the palmaris longus and its impact on grip strength in elite gymnasts and non-athletes. Int. J. Morphol., 37(4):1361-1369, 2019.

(Menevse, 2011; Fowlie et al., 2012; Koc, 2015). Though the potential contribution to hand strength was found to be not negligible, Fowlie et al. reported that bilateral and unilateral presence of PL in dominant hand was higher in elite athletes dealing with dominant-handed and two-handed cylindrical grip sports. Handball players with the presence of the PL muscle were found to have a better shooting speed and shooting power (Koc). Menevse noted a smaller reaction time in participants having PL compared to those lacking this muscle. Almost in all investigated age subgroups, Cetin et al. (2013) found higher grip strength in the case of PL presence but difference was not statistically significant. Maybe PL doesn't impact the grip strength but according to previous study it is very likely that presence of this muscle has some other advantages in athletes (Menevse; Koc). In addition, few studies reported a significant contribution of the PL muscle in thumb abduction (Fahrer, 1973; Gangata et al., 2010; Moore et al., 2018) and opposition movement of the fingers (Cetin et al.).

Considering that PL muscle could have potential advantages in gymnasts, this study aims to investigate the prevalence of PL in elite competitive artistic gymnasts and its impact on grip strength compared to a control group of moderately active non-athletes.

\section{MATERIAL AND METHOD}

This is a prospective controlled study where 370 subjects were recruited and divided in two groups. The investigated group included 170 elite junior and senior artistic gymnasts who compete at the international level and their trainers who also were elite artistic gymnasts, while the control group included 200 moderately active non-athletes, students of medicine. The study consisted of two clinical sets of examination: a search for the clinical presence of PL was initially conducted followed by the assessment of maximal grip strength. This study involved subjects willing to participate who had a normal range of motion of hand joints and wrist. We excluded individuals with a disease or congenital abnormality, prior upper limb surgery or injury that could precludes examination for the presence of the PL tendon. The study was approved by the independent Ethics Committee.

Clinical tests for PL presence: A single examiner tested bilaterally all subjects. All participants were initially asked to perform the Standard (Schaeffer`s) test. If the PL tendon was not visualized or palpable, six additional tests were performed to confirm PL tendon absence.

The following tests were used: Standard (Schaeffer`s) test: the subject is asked to oppose the thumb to the little finger and flex the wrist (Schaeffer, 1909).
Thompson's test: the subject is asked to make a fist, then flex the wrist and finally the thumb is opposed and flexed over the fingers (Thompson et al., 1921).

Mishra's test I: the metacarpophalangeal joints of all fingers are passively hyperextended by the examiner and the subject is asked to actively flex the wrist (Mishra, 2001).

Mishra's test II: the subject is asked to abduct the thumb against resistance with the wrist in slight palmar flexion (Mishra).

Pushpakumar's "two-finger sign" method: the subject is asked to fully extend the index and middle finger, the wrist and other fingers are flexed, and finally the thumb is fully opposed and flexed (Pushpakumar et al., 2004).

Gangata`s test: application of manual isometric resistance against wrist flexion onto the palmar surface at the level of the heads of the second to fifth metacarpals and, simultaneously, manual isometric resistance is applied against thumb abduction onto the lateral surface (where the palmar skin of the hand meets the dorsal skin) of the first metacarpo-phalangeal joint (Gangata).

Hiz-Ediz test: This was performed by applying resistance to flexion of fingers and wrist while all fingers were at the opposite position with the wrist at slight flexion (Hiz et al., 2011).

Grip strength assessment: Maximal grip strength was measured bilaterally with an electronic hand dynamometer (CAMRY, model EH101, Zhongshan, China). The device allowed continuous monitoring and recording of the grip strength. Measured values were expressed in kilograms $(\mathrm{kg})$ and divided in three categories (weak, normal, strong) according to the reference age-related intervals (http:// latodis-med.com/upload/pdf/dinamometru-digital-camryeh-101.pdf) recommended by the manufacturer of the applied dynamometer (CAMRY, model EH101) and grip strength norms according to Mathiowetz et al. (1986) for children aged 7 to 9 years. Measurements were performed in standardized positioning (Fess, 1992): sitting with the shoulder in adduction and neutral rotation, elbow flexed at 90 degrees, forearm in neutral position and wrist between 0 and 30 degrees of extension. After giving the needed instructions, the subject was asked to squeeze the handles of the dynamometer towards each other as hard as possible.

Statistical analyses. StatsDirect was used to perform the statistical analysis. Independent t-test and z-test were used to look for mean and proportion differences between the two studied groups. A paired t-test was used to look for 
differences between the sides of same subjects. Multiple linear regression analyses were conducted to search for potential predicators of the grip strength outcome. The X2 test was used to determine if there is a significant relationship between hand grip categories.

\section{RESULTS}

Characteristics of the sample: The total sample of 370 subjects included 155 females and 215 males.

The gymnastic group included 170 athletes ( 55 females and 115 males) with a mean age of $19.9 \pm 12.42$ years (range: 7 to 65 ). The mean training period was $9.6 \pm 6$ years, ranging from 2 to 30 years. The demographic characteristics of the investigated group are shown in Table I. Fourteen (8.2\%) subjects had left hand dominance. All gymnasts but six performed mixed disciplines; 4 trained on the pommel horse, 1 on parallel bars and 1 on the balance beam.

Table I. Demographic characteristics of the investigated group.

\begin{tabular}{llcccc}
\hline Country & $\begin{array}{l}\text { Sample } \\
\text { size }\end{array}$ & $\begin{array}{c}\text { Mean age } \\
\text { (years) }\end{array}$ & Males & Females & $\begin{array}{c}\text { Training } \\
\text { period (years) }\end{array}$ \\
\hline Croatia & 41 & $22.3 \pm 13.4$ & 31 & 10 & $10.8 \pm 5.4$ \\
Serbia & 48 & $20 \pm 13.5$ & 33 & 15 & $8.4 \pm 5.8$ \\
Bulgaria & 9 & $22.1 \pm 10.6$ & 9 & 0 & $10.1 \pm 4.9$ \\
Slovenia & 42 & $17.4 \pm 10.3$ & 13 & 29 & $8.8 \pm 6.2$ \\
Denmark & 6 & $21 \pm 14.9$ & 6 & 0 & $12 \pm 10$ \\
France & 4 & $19.2 \pm 10.7$ & 4 & 0 & $15 \pm 8.3$ \\
Romania & 15 & $18.1 \pm 12.8$ & 14 & 1 & $9.6 \pm 6.9$ \\
South Africa & 5 & $20.2 \pm 12.5$ & 5 & 0 & $10.4 \pm 7.2$ \\
Total & 170 & $19.9 \pm 12.42$ & 115 & 55 & $9.6 \pm 6$ \\
\hline
\end{tabular}

The grip strength on right side was $3 \%$ higher in right-handers and $0.2 \%$ in left-handers. The in grip strength in gymnasts who had unilateral PL agenesis on right side was $9.6 \%$ higher on right side while in gymnasts who had PL agenesis on left side the grip strength of the left hand was $4.6 \%$ higher.

Table II. PL prevalence of the investigated group.

\begin{tabular}{|c|c|c|c|c|c|c|}
\hline Country & $\begin{array}{c}\text { Crude prevalence } \\
\text { of PL }\end{array}$ & $\begin{array}{c}\text { Bilateral } \\
\text { prevalence of PL }\end{array}$ & $\begin{array}{c}\text { Bilateral absence } \\
\text { of PL }\end{array}$ & $\begin{array}{c}\text { True prevalence } \\
\text { of PL }\end{array}$ & $\begin{array}{c}\text { Right } \\
\text { absence }\end{array}$ & $\begin{array}{c}\text { Left } \\
\text { absence }\end{array}$ \\
\hline Croatia & $34(82.9 \%)$ & $31(75.6 \%)$ & $7(17 \%)$ & $65(79.3 \%)$ & $0(0 \%)$ & $3(7.3 \%)$ \\
\hline Serbia & $37(77.1 \%)$ & $29(60.4 \%)$ & $11(22.9 \%)$ & $66(68.8 \%)$ & $2(4.2 \%)$ & $6(12.5 \%)$ \\
\hline Bulgaria & $6(66.7) \%$ & $3(33.3 \%)$ & $3(33.3 \%)$ & $9(50 \%)$ & $2(22.2 \%)$ & $1(11.1 \%)$ \\
\hline Slovenia & $36(85.7 \%)$ & $30(71.4 \%)$ & $6(14.3 \%)$ & $66(78.6 \%)$ & $3(7.1 \%)$ & $3(7.1 \%)$ \\
\hline Denmark & $6(100 \%)$ & $5(83.3 \%)$ & $0(0 \%)$ & $11(91.7 \%)$ & $1(16.7 \%)$ & $0(0 \%)$ \\
\hline France & $2(50 \%)$ & $2(50 \%)$ & $2(50 \%)$ & $4(50 \%)$ & $0(0 \%)$ & $0(0 \%)$ \\
\hline Romania & $13(86.7 \%)$ & $10(66.7 \%)$ & $2(13.3 \%)$ & $23(76.7 \%)$ & $2(13.3 \%)$ & $1(6.7 \%)$ \\
\hline South Africa & $4(80 \%)$ & $4(80 \%)$ & $1(20 \%)$ & $8(80 \%)$ & $0(0 \%)$ & $0(0 \%)$ \\
\hline Total & $138(81.2 \%)$ & $114(67.1 \%)$ & $32(18.8 \%)$ & $252(74.1 \%)$ & $10(5.9 \%)$ & $14(8.2 \%)$ \\
\hline
\end{tabular}

Table III. PL presence in the investigated and control group.

\begin{tabular}{lcccccc}
\hline \multicolumn{1}{c}{ PL } & \multicolumn{2}{c}{ Investigated group (gymnasts) } & \multicolumn{3}{c}{ Control group (students) } \\
& males & females & total & males & females & total \\
\hline Bilateral presence & $76(66.1 \%)$ & $38(69.1 \%)$ & $114(67.1 \%)$ & $63(63 \%)$ & $69(69 \%)$ & $132(66 \%)$ \\
Bilateral absence & $22(19.1 \%)$ & $10(18.2 \%)$ & $32(18.8 \%)$ & $24(24 \%)$ & $12(12 \%)$ & $36(18 \%)$ \\
Right absence & $8(7 \%)$ & $2(3.6 \%)$ & $10(5.9 \%)$ & $3(3 \%)$ & $8(8 \%)$ & $11(5.5 \%)$ \\
Left absence & $9(7.8 \%)$ & $5(9.1 \%)$ & $14(8.2 \%)$ & $10(10 \%)$ & $11(11 \%)$ & $21(10.5 \%)$ \\
Total & 115 & 55 & 170 & 100 & 100 & 200 \\
\hline
\end{tabular}


ERIC, M.; YAMMINE, K.; VASIC, G.; DEJANOVIC, M. \& KARABA JAKOVLJEVIC, D. Prevalence of the palmaris longus and its impact on grip strength in elite gymnasts and non-athletes. Int. J. Morphol., 37(4):1361-1369, 2019.

Table IV. The age related measured mean values of grip strength and PL presence in gymnasts.

\begin{tabular}{|c|c|c|c|c|c|c|c|}
\hline Sex & Age (years) & No of subjects & hand & PL & No of hands & Mean grip strength & $\mathrm{p}$ \\
\hline \multirow{44}{*}{$\begin{array}{c}\text { Males } \\
(115)\end{array}$} & $7-9$ & 10 & Right & Present & 9 & $17.4 \pm 2.7$ & 0.8820 \\
\hline & & & & Absent & 1 & $17.7 \pm 0$ & \\
\hline & & & Left & Present & 8 & $15.5 \pm 2.7$ & 0.2120 \\
\hline & & & & Absent & 2 & $18.4 \pm 3.4$ & \\
\hline & $10-11$ & 18 & Right & Present & 17 & $21.8 \pm 4.2$ & 0.8636 \\
\hline & & & & Absent & 1 & $22.3 \pm 0$ & \\
\hline & & & Left & Present & 16 & $21.3 \pm 4.1$ & 0.7398 \\
\hline & & & & Absent & 2 & $20.3 \pm 1.5$ & \\
\hline & $12-13$ & 12 & Right & Present & 10 & $26.1 \pm 5.2$ & 0.9609 \\
\hline & & & & Absent & 2 & $25.9 \pm 6.9$ & \\
\hline & & & Left & Present & 11 & $23.7 \pm 4.6$ & 0.1266 \\
\hline & & & & Absent & 1 & $29.4 \pm 0$ & \\
\hline & $14-15$ & 14 & Right & Present & 11 & $34.2 \pm 12.7$ & 0.4556 \\
\hline & & & & Absent & 3 & $40.6 \pm 12.2$ & \\
\hline & & & Left & Present & 9 & $31.7 \pm 10.0$ & 0.1373 \\
\hline & & & & Absent & 5 & $42.5 \pm 15.6$ & \\
\hline & $16-17$ & 12 & Right & Present & 6 & $46.6 \pm 7.0$ & 0.3195 \\
\hline & & & & Absent & 6 & $52.5 \pm 12.0$ & \\
\hline & & & Left & Present & 7 & $48.3 \pm 8.5$ & 0.4794 \\
\hline & & & & Absent & 5 & $53.9 \pm 17.6$ & \\
\hline & $20-24$ & 6 & Right & Present & 4 & $46.2 \pm 6.9$ & 0.9430 \\
\hline & & & & Absent & 2 & $45.8 \pm 6.6$ & \\
\hline & & & Left & Present & 4 & $48.3 \pm 11.1$ & 0.8607 \\
\hline & & & & Absent & 2 & $46.7 \pm 6.9$ & \\
\hline & $25-29$ & 9 & Right & Present & 5 & $53.2 \pm 2.0$ & 0.0182 \\
\hline & & & & Absent & 4 & $59.4 \pm 4.0$ & \\
\hline & & & Left & Present & 4 & $45.1 \pm 6.2$ & 0.0294 \\
\hline & & & & Absent & 5 & $56.5 \pm 6.2$ & \\
\hline & $30-34$ & 10 & Right & Present & 7 & $56.0 \pm 14.8$ & 0.5570 \\
\hline & & & & Absent & 3 & $62.2 \pm 14.9$ & \\
\hline & & & Left & Present & 8 & $56.6 \pm 12.8$ & 0.9323 \\
\hline & & & & Absent & 2 & $55.7 \pm 11.0$ & \\
\hline & $35-39$ & 11 & Right & Present & 6 & $53.4 \pm 8.4$ & 0.3856 \\
\hline & & & & Absent & 5 & $57.4 \pm 5.8$ & \\
\hline & & & Left & Present & 8 & $50.0 \pm 8.4$ & 0.4896 \\
\hline & & & & Absent & 3 & $54.3 \pm 10.5$ & \\
\hline & $40-44$ & 7 & Right & Present & 5 & $52.9 \pm 5.1$ & 0.9850 \\
\hline & & & & Absent & 2 & $53.0 \pm 12.7$ & \\
\hline & & & Left & Present & 5 & $50.5 \pm 6.0$ & 0.3195 \\
\hline & & & & Absent & 2 & $56.2 \pm 6.6$ & \\
\hline & $45-65$ & 6 & Right & Present & 5 & $52.0 \pm 7.4$ & 0.3924 \\
\hline & & & & Absent & 1 & $57.2 \pm 0$ & \\
\hline & & & Left & Present & 4 & $53.7 \pm 4.2$ & 0.5142 \\
\hline & & & & Absent & 2 & $50.9 \pm 5.4$ & \\
\hline
\end{tabular}




\begin{tabular}{|c|c|c|c|c|c|c|c|}
\hline Sex & Age (years) & No of subjects & hand & PL & No of hands & Mean grip & $\mathrm{p}$ \\
\hline \multirow[t]{20}{*}{ Females (55) } & $10-11$ & 25 & Right & Present & 20 & $19.5 \pm 4.2$ & 0.1303 \\
\hline & & & & Absent & 5 & $16.2 \pm 4.1$ & \\
\hline & & & Left & Present & 21 & $18.6 \pm 3.8$ & 0.1750 \\
\hline & & & & Absent & 4 & $15.7 \pm 3.4$ & \\
\hline & $12-13$ & 16 & Right & Present & 13 & $27.5 \pm 6.5$ & 0.8161 \\
\hline & & & & Absent & 3 & $26.6 \pm 0.8$ & \\
\hline & & & Left & Present & 11 & $26.4 \pm 6.0$ & 0.8786 \\
\hline & & & & Absent & 5 & $26.9 \pm 1.8$ & \\
\hline & $18-19$ & 5 & Right & Present & 3 & $34.2 \pm 7.5$ & 0.5680 \\
\hline & & & & Absent & 2 & $30.7 \pm 0.6$ & \\
\hline & & & Left & Present & 2 & $37.2 \pm 9.3$ & 0.3853 \\
\hline & & & & Absent & 3 & $32.2 \pm 0.5$ & \\
\hline & $20-24$ & 4 & Right & Present & 4 & $33.6 \pm 4.7$ & I \\
\hline & & & & Absent & 0 & 0 & \\
\hline & & & Left & Present & 4 & $33.9 \pm 5.1$ & I \\
\hline & & & & Absent & 0 & 0 & \\
\hline & $35-65$ & 5 & Right & Present & 3 & $35.3 \pm 5.8$ & 0.6493 \\
\hline & & & & Absent & 2 & $32.8 \pm 5.3$ & \\
\hline & & & Left & Present & 2 & $33.1 \pm 4.3$ & 0.8504 \\
\hline & & & & Absent & 3 & $34.0 \pm 5.2$ & \\
\hline
\end{tabular}

The age related measured mean values of grip strength and PL presence in gymnasts are shown in Table IV.

Multivariate analysis: Setting the grip strength as the outcome, multiple linear regression analyses with sex and PL presence on the right side as predicators, yielded significant positive correlation for male sex $(\mathrm{P}<0.0001)$ and significant negative correlation with PL presence $(\mathrm{P}=0.0006)$. The model had a $\mathrm{R}^{2}=24.83 \%(\mathrm{P}<0.0001)$. Similar results were found on the left side with a $\mathrm{R}^{2}=23.04 \%(\mathrm{P}<0.0001)$.

\section{PL in students}

PL prevalence: The crude prevalence of PL was found to be $82.0 \%$ (164 out of 200 subjects) and the true prevalence at $74.0 \%$ (296 out of 400 forearms). The detailed results are shown in Table III.

When analyzing the interaction between side and sex, PL prevalence values demonstrated that in males and females, a clinical absence on one side yielded the same on the other side in $64.9 \%$ and $38.7 \%$, respectively.

Maximum grip strength: The mean maximum grip strengths on the right and left side were found to be $40.77 \pm 11.6$ and $38.4 \pm 10.9$, respectively. One way analysis of variance yielded significance in favor of the right side $(\mathrm{P}=0.038)$.

Table V. The age related measured mean values of grip strength and PL presence in students.

\begin{tabular}{|c|c|c|c|c|c|c|c|}
\hline Sex & Age (years) & $\begin{array}{c}\text { No of } \\
\text { subjects }\end{array}$ & hand & PL & No of hands & $\begin{array}{c}\text { Mean grip } \\
\text { strength }\end{array}$ & $\mathrm{p}$ \\
\hline \multirow{8}{*}{ Males } & \multirow{4}{*}{$18-19$} & \multirow{4}{*}{69} & \multirow{2}{*}{ Right } & Present & 50 & $49.9 \pm 7.6$ & \multirow{2}{*}{0.6267} \\
\hline & & & & Absent & 19 & $48.8 \pm 8.1$ & \\
\hline & & & \multirow{2}{*}{ Left } & Present & 47 & $45.4 \pm 7.6$ & \multirow{2}{*}{0.1132} \\
\hline & & & & Absent & 22 & $48.7 \pm 8.2$ & \\
\hline & \multirow{4}{*}{$20-24$} & \multirow{4}{*}{31} & \multirow{2}{*}{ Right } & Present & 23 & $51.2 \pm 7.3$ & \multirow{2}{*}{0.1263} \\
\hline & & & & Absent & 8 & $56.1 \pm 8.5$ & \\
\hline & & & \multirow{2}{*}{ Left } & Present & 19 & $50.1 \pm 6.5$ & \multirow{2}{*}{0.5259} \\
\hline & & & & Absent & 12 & $48.4 \pm 7.9$ & \\
\hline \multirow{8}{*}{ Females } & \multirow{4}{*}{$18-19$} & \multirow{4}{*}{72} & \multirow{2}{*}{ Right } & Present & 65 & $31.3 \pm 4.5$ & \multirow{2}{*}{0.4622} \\
\hline & & & & Absent & 17 & $30.4 \pm 4.5$ & \\
\hline & & & \multirow{2}{*}{ Left } & Present & 64 & $29.8 \pm 4.6$ & \multirow{2}{*}{0.1879} \\
\hline & & & & Absent & 18 & $28.3 \pm 3.6$ & \\
\hline & \multirow{4}{*}{$20-24$} & \multirow{4}{*}{18} & Right & Present & 15 & $30.9 \pm 4.6$ & \multirow{2}{*}{0.8750} \\
\hline & & & Right & Absent & 3 & $31.3 \pm 3.3$ & \\
\hline & & & \multirow{2}{*}{ Left } & Present & 13 & $29.5 \pm 4.0$ & \multirow{2}{*}{0.8537} \\
\hline & & & & Absent & 5 & $29.1 \pm 4.1$ & \\
\hline
\end{tabular}


The grip strength on right side was $6.5 \%$ higher in right-handers and $1.8 \%$ in left-handers. The grip strength in students who had right-sided unilateral PL agenesis was $1.9 \%$ higher on right side while in students who had PL agenesis on left side the grip strength of the right hand was $4.8 \%$ higher.

The age related measured mean values of grip strength and PL presence in students are shown in Table $\mathrm{V}$.

Multivariate analysis: Setting the grip strength as the outcome, multiple linear regression analyses with sex and PL presence on the right side as predicators, yielded significant positive correlation for male sex $(\mathrm{P}<0.0001)$ and non-significant negative correlation with PL presence $(\mathrm{P}=0.9)$. The model had a $\mathrm{R}^{2}=70.14 \%(\mathrm{P}<0.0001)$. Similar results were found on the left side with a $\mathrm{R}^{2}=67.6$ $\%(\mathrm{P}<0.0001)$.

Comparison of grip strength categories of both groups: The grip strength on the right side in males was stronger in investigated group $(34.8 \%$ vs. $21.0 \%)$ and this difference was statistically significant $\left(X^{2}=5.00\right.$, $\mathrm{p}=0.03)$ while no significance was found in females $(40.0$ $\%$ vs. $40.0 \%$ ) where the $p$ value was 1 . The grip strength on the left side was stronger in investigated group, in males $(29.6 \%$ vs. $12.0 \%)$ yielded significant difference $\left(\mathrm{X}^{2}=9.81, \mathrm{p}=0.001\right)$ but in females $(43.6 \%$ vs. $32.0 \%)$ difference was not statistically significant $\mathrm{p}=0.2$ (Table VI).

Table VI. Grip strength category and PL prevalence in the investigated (gymnasts) and control (students) group

\begin{tabular}{|c|c|c|c|c|c|c|}
\hline \multirow{2}{*}{$\begin{array}{l}\text { Males } \\
\text { (investigated group) }\end{array}$} & \multicolumn{3}{|c|}{ Right hand } & \multicolumn{3}{|c|}{ Left hand } \\
\hline & & & & & & \\
\hline Grip strength & $\mathrm{N}$ & PL present & PL absent & $\mathrm{N}$ & PL present & PL absent \\
\hline S trong & $40(34.8 \%)$ & $26(30.6 \%)$ & $14(46.7 \%)$ & $34(29.6 \%)$ & $22(26.2 \%)$ & $12(38.7 \%)$ \\
\hline Normal & $72(62.6 \%)$ & $56(65.9 \%)$ & $16(53.3 \%)$ & $76(66.1 \%)$ & $57(67.9 \%)$ & $19(61.3 \%)$ \\
\hline Weak & $3(2.6 \%)$ & $3(3.5 \%)$ & - & $5(4.3 \%)$ & $5(5.9 \%)$ & - \\
\hline Total & $115(100 \%)$ & $85(100 \%)$ & $30(100 \%)$ & $115(100 \%)$ & $84(100 \%)$ & $31(100 \%)$ \\
\hline \multicolumn{7}{|c|}{$\begin{array}{l}\text { Females } \\
\text { (investigated group) }\end{array}$} \\
\hline Grip strength & $\mathrm{N}$ & PL present & PL absent & $\mathrm{N}$ & PL present & PL absent \\
\hline S trong & $22(40.0 \%)$ & $16(37.2 \%)$ & $6(50.0 \%)$ & $24(43.6 \%)$ & $14(35.0 \%)$ & $10(66.7 \%)$ \\
\hline Normal & $33(60.0 \%)$ & $27(62.8 \%)$ & $6(50.0 \%)$ & $31(56.4 \%)$ & $26(65.0 \%)$ & $5(33.3 \%)$ \\
\hline Weak & - & - & - & - & - & - \\
\hline Total & $55(100 \%)$ & $43(100 \%)$ & $12(100 \%)$ & $55(100 \%)$ & $40(100 \%)$ & $15(100 \%)$ \\
\hline \multicolumn{7}{|c|}{$\begin{array}{l}\text { Males } \\
\text { (control group) }\end{array}$} \\
\hline Grip strength & $\mathrm{N}$ & PL present & PL absent & $\mathrm{N}$ & PL present & PL absent \\
\hline S trong & $21(21.0 \%)$ & $16(21.9 \%)$ & $5(18.5 \%)$ & $12(12.0 \%)$ & $6(9.1 \%)$ & $6(17.6 \%)$ \\
\hline Normal & $77(77.0 \%)$ & $56(76.7 \%)$ & $21(77.8 \%)$ & $84(84.0 \%)$ & $57(86.4 \%)$ & $27(79.4 \%)$ \\
\hline Weak & $2(2.0 \%)$ & $1(1.4 \%)$ & $1(3.7 \%)$ & $4(4.0 \%)$ & $3(4.5 \%)$ & $1(2.9 \%)$ \\
\hline Total & $100(100 \%)$ & $73(100 \%)$ & $27(100 \%)$ & $100(100 \%)$ & $66(100 \%)$ & $34(100 \%)$ \\
\hline \multicolumn{7}{|c|}{$\begin{array}{l}\text { Females } \\
\text { (control group) }\end{array}$} \\
\hline Grip strength & $\mathrm{N}$ & PL present & PL absent & $\mathrm{N}$ & PL present & PL absent \\
\hline S trong & $40(40.0 \%)$ & $34(42.5 \%)$ & $6(30.0 \%)$ & $32(32.0 \%)$ & $28(36.4 \%)$ & $4(17.4 \%)$ \\
\hline Normal & $59(59.0 \%)$ & $45(56.3 \%)$ & $14(70.0 \%)$ & $67(67.0 \%)$ & $48(62.3 \%)$ & $19(82.6 \%)$ \\
\hline Weak & $1(1.0 \%)$ & $1(1.2 \%)$ & - & $1(1.0 \%)$ & $1(1.3 \%)$ & - \\
\hline Total & $100(100 \%)$ & $80(100 \%)$ & $20(100 \%)$ & $100(100 \%)$ & $77(100 \%)$ & $23(100 \%)$ \\
\hline
\end{tabular}

\section{DISCUSSION}

According to the results of our study overall PL absence in gymnasts and students was $33.9 \%$ and $37 \%$, respectively.
Bilateral absence was more common than unilateral, predominately noted on left side in both study groups. There 
are a numerous scientific papers that described similar findings (Ceyhan \& Mavt; Kose et al., 2009; Eric' et al., 2011), however, the meta-analysis of Yammine showed no statistically differences between unilateral and bilateral absence with predominance of PL absence on the right side.

In the last decades, the functional value of this muscle increasingly intrigues investigators. There are divided opinions about PL functional importance and reparation after its injury. Verdan \& Poulenas advocated the opinion that PL has small importance and because of that its reparation is not necessary, but authors of the later studies usually advocated its reparation (Brand \& Hollister, 1993; Sarangapani \& Brown, 1977; Sebastin et al.). Their attitude was defended by the facts that PL protects the median nerve, its function will be restored and its preservation gives possibility to use it as a tendon graft or tendon transfer (Sarangapani \& Brown; Brand \& Hollister; Sebastin et al.). However, some authors noted significant positive correlation between PL presence and Dupuytren's contracture (Powell et al., 1986) as well as carpal tunnel syndrome (Keese et al., 2006).

Searching the literature, the authors of this paper noticed that there is no studies to date that have investigated whether the PL presence contributes to grip strength in gymnasts. Our results show that the mean maximum grip strength was higher in students but it was expected considering the age range of gymnasts involved in the study (7 to 65 years). Even 109 (64.1\%) gymnasts were younger than the age of 18 while the age range of students was between 18 and 25. However, according to the age-related norm values of the hand grip strength, $35.3 \%$ of investigated gymnasts had strong grip strength in comparison with 26.3 $\%$ of students. Around 1/3 of male and more than $2 / 5$ of female gymnasts had strong grip strength. Students had normal grip strength more frequently $(71.8 \%)$ in comparison with gymnasts $(62.4 \%)$. That was expected with regard to the level of gymnasts training.

Until now, only a few studies investigated contribution of the PL muscle to the grip strength (Sebastin et al.; Gangata et al.; Koc \& Aycan, 2011; Kose et al., 2012; Fowlie et al.; Cetin et al.; Barkáts, 2014; Vercruyssen et al., 2016). The results of our study, in line with many others (Sebastin et al.; Kose et al., 2009; Gangata et al.; Cetin et $a l$; : Vercruyssen et al.), show that the grip strength was not correlated with PL presence. Reason for that could be a contribution of the PL muscle in thumb abduction (Fahrer; Gangata et al.; Moore et al.) while position of the grip involves thumb adduction. Three studies demonstrated that the presence of the PL muscle may positively affect the grip strength (Koc \& Aycan; Fowlie et al.; Barkáts).
Generally, it is accepted that the grip strength of the dominant hand in right-handed subjects is $10 \%$ stronger than the nondominant left hand while in left-handed subjects the difference ranges from 0 to $5 \%$ (Petersen et al., 1989) in favor of the nondominant right hand. Some previous studies confirmed that this rule is not always true (Barkáts). According to the results of our study, the difference between right and left hand grip strength in right-handed subjects ranged from $3 \%$ (gymnasts) to $6.5 \%$ (students) while in lefthanded ranged from $0.2 \%$ (gymnasts) to $1.8 \%$ (students). A smaller difference between dominant and non-dominant hand grip strength in gymnasts can be explained by the level of gymnasts training and the equal usage of both hands.

Taking in account that it is very difficult to quantify the functional contribution of the PL muscle separately from the other muscles of the anterior forearm compartment we additionally analyzed hand grip strength in those subjects who had unilateral absence of the PL muscle. In gymnasts, the difference of right and left hand grip strength was in favor to the side where the PL was absent (9.6\% right and $4.5 \%$ left). In all students with unilateral PL absence, the difference of grip strength was in favor to the right side (right absence $1.9 \%$; left absence $4.8 \%$ ). Accordingly, we noticed that in students the grip strength slightly decreases in case of PL absence while the values in gymnasts are contrary; nevertheless, our findings suggest that the PL presence doesn't impact the grip strength where the mean value of grip strength in some age groups was higher on the side where the PL was absent. In relation to grip strength's correlation with PL, the study has some limitations; the small sample size of subjects with unilateral PL absence (24 gymnasts and 32 students), the wide variation of the age range of gymnasts and the presence of different ethnic groups (from European countries and South Africa).

Ideally, the best scenario to study the PL impact on grip strength would be on subjects with a present PL which is to be removed for a reconstructive non-hand surgery, taking pre and post-operative grip strength measurements. The congenital absence of PL may not necessarily be the same as loss of this muscle during the life because of its injury or surgery.

As a conclusion, the results of our study show that the presence of the PL doesn't affect the hand grip strength in gymnasts. Concerning the small number of gymnasts especially those with unilateral PL presence we couldn't be sure are the present results a product of accidental coincidence. Therefore, further research is warranted to assess PL contribution to hand grip strength and to other hand functions that could be of significant importance for athletes and non-athletes. 
ERIC, M.; YAMMINE, K.; VASIC, G.; DEJANOVIC, M. \& KARABA JAKOVLJEVIC, D.Prevalencia del músculo palmar largo y su impacto en la fuerza de agarre en gimnastas de elite y no atletas. Int. J. Morphol., 37(4):1361-1369, 2019.

RESUMEN: La presencia del músculo palmar largo (MPL) en atletas de élite tiene el potencial de aportar mayor fuerza a la mano, un tiempo de reacción menor, mejor velocidad de tiro y potencia. El objetivo de este estudio fue investigar la prevalencia de MPL en las gimnastas artísticas competitivas de élite y su impacto en la fuerza de agarre en comparación con un grupo control de no atletas moderadamente activos. El estudio incluyó 370 sujetos divididos en dos grupos (170 gimnastas artísticas de élite y 200 no atletas moderadamente activos, estudiantes de medicina). El estudio consistió en dos series clínicas de examen: inicialmente se realizó una búsqueda de la presencia clínica de MPL, seguido de la evaluación de la fuerza máxima de agarre. Se realizaron pruebas estándar y seis pruebas adicionales para confirmar la ausencia del tendón del MPL. La máxima fuerza de agarre se midió bilateralmente con un dinamómetro de mano electrónico. La ausencia bilateral fue más común que unilateral, predominantemente observada en el lado izquierdo en ambos grupos de estudio. La ausencia unilateral de MPL se correlacionó con una menor fuerza de agarre en los estudiantes, mientras que en gimnastas se encontró lo contrario. El valor medio de la fuerza de agarre en algunos grupos de edad fue mayor en el lado donde el MPL estaba ausente. Los resultados de nuestro estudio muestran que la presencia de MPL no afecta la fuerza de agarre de la mano en gimnastas. Debido a la baja incidencia de ausencia unilateral de MPL, se justifica una investigación adicional de gran tamaño para evaluar la contribución de MPL a la fuerza de agarre de la mano y otras funciones de la mano que podrían ser de gran importancia para los atletas y no atletas.

PALABRAS CLAVE: Músculo palmar largo; Prevalencia; Fuerza de agarre de la mano; Atletas de elite; Gimnastas.

\section{REFERENCES}

Abdolahzadeh Lahiji, F.; Ashoori, K. \& Dahmardehei, M. Prevalence of palmaris longus agenesis in a hospital in Iran. Arch. Iran. Med., 16(3):187-8, 2013.

Ahn, D. S.; Yoon, E. S.; Koo, S. H. \& Park, S. H. A prospective study of the anatomic variations of the median nerve in the carpal tunnel in Asians. Ann. Plast. Surg., 44(3):282-7, 2000.

Barkáts, N. Palmaris longus, a muscle that lost its function, or not? A pilot study. Sci. Educ. New Dimens. Nat. Tech. Sci., 2(4):6-8, 2014.

Brand, P. W. \& Hollister, A. M. Mechanics of Individual Muscles at Individual Joints. In: Brand, P. W. \& Hollister, A. M. (Eds.). Clinical Mechanics of the Hand. 2nd ed. St. Louis, Mosby Year Book, 1993. pp.254-352.

Cetin, A.; Genc, M.; Sevil, S. \& Coban, Y. K. Prevalence of the palmaris longus muscle and its relationship with grip and pinch strength: a study in a Turkish pediatric population. Hand (N. Y.), 8(2):215-20, 2013.

Ceyhan, O. \& Mavt, A. Distribution of agenesis of palmaris longus muscle in 12 to 18 years old age groups. Indian J. Med. Sci., 51(5):156-60, 1997.

Eric, M.; Koprivcic, I.; Vucinic, N.; Radic, R.; Krivokuca, D.; Leksan, I. \&
Selthofer, R. Prevalence of the palmaris longus in relation to the hand dominance. Surg. Radiol. Anat., 33(6):481-4, 2011.

Eric, M.; Krivokuca, D.; Savovic, S.; Leksan, I. \& Vucinic, N. Prevalence of the palmaris longus through clinical evaluation. Surg. Radiol. Anat., 32(4):357-61, 2010

Fahrer, M. Proceedings: The role of the palmaris longus muscle in the abduction of the thumb. J. Anat., 116(Pt. 3):476, 1973.

Fess, E. E. Grip Strength. In: Casanova, J. S. (Ed.). Clinical Assessment Recommendations. 2nd ed. Chicago, American Society of Hand Therapists, 1992. pp.41-5.

Fowlie, C.; Fuller, C. \& Pratten, M. K. Assessment of the presence/absence of the palmaris longus muscle in different sports, and elite and nonelite sport populations. Physiotherapy, 98(2):138-42, 2012.

Gangata, $\mathrm{H}$. The clinical surface anatomy anomalies of the palmaris longus muscle in the Black African population of Zimbabwe and a proposed new testing technique. Clin. Anat., 22(2):230-5, 2009.

Gangata, H.; Ndou, R. \& Louw, G. The contribution of the palmaris longus muscle to the strength of thumb abduction. Clin. Anat., 23(4):431-6, 2010.

Hiz, Ö.; Ediz, L.; Ceylan, M. F.; Gezici, E.; Gülcü, E. \& Erden, M. Prevalence of the absence of palmaris longus muscle assessed by a new examination test (Hiz-Ediz Test) in the population residing in the area of Van, Turkey. J. Clin. Exp. Investig., 2(3):254-9, 2011.

Karahan, A. Y.; Bakdik, S.; Özen, K. E.; Arslan, S.; Karpuz, S.; Yilmaz, N.; Yildirim, P.; Oncu, F. \& Cicekcibasi, A. E. The effect of the palmaris longus muscle on wrist flexion and extension strength. Isokinet. Exerc. Sci., 25(4):243-7, 2017

Keese, G. R.; Wongworawat, M. D. \& Frykman, G. The clinical significance of the palmaris longus tendon in the pathophysiology of carpal tunnel syndrome. J. Hand Surg. Br., 31(6):657-60, 2006.

Kleinert, H. E.; Pulvertaft, R. G. \& Smith, D. J. Flexor Tendon Grafting in the Hand. In: Jupiter, J. B. (Ed.). Flynn's Hand Surgery. Baltimore, Williams \& Wilkins, 1991. pp.283-99.

Koc, H. \& Aycan, K. Hand grip strength in individuals with and without the palmaris longus. Isokinet. Exerc. Sci., 19(4):305-9, 2011.

Koc, H. Study of the impact of palmaris longus muscle on shooting velocity in handball players. Anthropologist, 20(3):651-5, 2015.

Kose, O.; Adanir, O.; Cirpar, M.; Kurklu, M. \& Komurcu, M. The prevalence of absence of the palmaris longus: a study in Turkish population. Arch. Orthop. Trauma Surg., 129(5):609-11, 2009.

Kose, O.; Adanır, O.; Oto, M.; Kürklü, M. \& Kömürcü, M. The contribution of the palmaris longus muscle to the grip strength. Hand Microsurg., 1(1):7-9, 2012

Kyung, D. S.; Lee, J. H.; Choi, I. J. \& Kim, D. K. Different frequency of the absence of the palmaris longus according to assessment methods in a Korean population. Anat. Cell Biol., 45(1):53-6, 2012.

Mathiowetz, V.; Wiemer, D. M. \& Federman, S. M. Grip and pinch strength: norms for 6- to 19-year-olds. Am. J. Occup. Ther, 40(10):705-11, 1986.

Menevse, A. Examination of the relationship between muscle palmaris longus and reaction time. World Appl. Sci. J., 12(1):114-8, 2011.

Mishra, S. Alternative tests in demonstrating the presence of palmaris longus. Indian J. Plast. Surg., 34:12-4, 2001.

Moore, C. W.; Fanous, J. \& Rice, C. L. Revisiting the functional anatomy of the palmaris longus as a thenar synergist. Clin. Anat., 31(6):760-70, 2018.

Petersen, P.; Petrick, M.; Connor, H. \& Conklin, D. Grip strength and hand dominance: challenging the $10 \%$ rule. Am. J. Occup. Ther, 43(7):4447, 1989.

Powell, B. W.; McLean, N. R. \& Jeffs, J. V. The incidence of a palmaris longus tendon in patients with Dupuytren's disease. J. Hand Surg. Br., 11(3):382-4, 1986.

Pushpakumar, S. B.; Hanson, R. P. \& Carroll, S. The 'two finger' sign. Clinical examination of palmaris longus (PL) tendon. Br. J. Plast. Surg., 57(2):184-5, 2004.

Raouf, H. A.; Kader, G. A.; Jaradat, A.; Dharap, A.; Fadel, R. \& Salem, A. H. Frequency of palmaris longus absence and its association with other 
anatomical variations in the Egyptian population. Clin. Anat., 26(5):5727, 2013.

Saldana, M. J. Primary Extensor Tendon Grafts in Zones 5 to 7. In: Blair, W. E. (Ed.). Techniques in Hand Surgery. Baltimore, Williams \&Wilkins, 1996. pp.587.

Sarangapani, K. \& Brown, H. G. Cut palmaris longus tendon--to repair or not to repair? Hand, 9(1):86-7, 1977.

Schaeffer, J. P. On the variations of the palmaris longus muscle. Anat. Rec., 3:275-8, 1909.

Sebastin, S. J.; Lim, A. Y.; Bee, W. H.; Wong, T. C. \& Methil, B. V. Does the absence of the palmaris longus affect grip and pinch strength? $J$. Hand Surg. Br., 30(4):406-8, 2005.

Smith, P. Lister's the Hand-Diagnosis and Indications. London, Churchill Livingstone, 2002

Snell, R. S. Clinical Anatomy by Regions. $9^{\text {th }}$ ed. Baltimore, Lippincott Williams \& Wilkins, 2012.

Standring, S. Gray's Anatomy. 41 ${ }^{\text {st }}$ ed. Edinburg, Elsevier Churchill Livingstone, 2016.

Thompson, J. W.; McBatts, J. \& Danforth, C. H. Hereditary and racial variation in the musculus palmaris longus. Am. J. Phys. Anthropol., 4(2):205-18, 1921

Tubbs, R. S.; Shoja, M. M. \& Loukas, M. Bergman's Comprehensive Encyclopedia of Human Anatomic Variation. Hoboken, John Wiley \& Sons Inc., 2016.

Vercruyssen, J.; Scafoglieri, A.; \& Cattrysse, E. The impact of palmaris longus muscle on function in sports: an explorative study in elite tennis players and recreational athletes. J. Funct. Morphol. Kinesiol., 1(2):16782, 2016.

Verdan, C. \& Poulenas, I. Anatomic and functional relations between the tendons of the long palmar muscle and the long flexor muscle of the thumb at their crossing in the carpus. Ann. Chir. Plast., 20(2):191-6, 1975.

Yammine, K. Clinical prevalence of palmaris longus agenesis: a systematic review and meta-analysis. Clin. Anat., 26(6):709-18, 2013.
Corresponding author:

Prof. Mirela Eric MD, PhD

Department of Anatomy

Faculty of Medicine

University of Novi Sad

Hajduk Veljkova 3

21000 Novi Sad

SERBIA

Email: mirela.eric@mf.uns.ac.rs mirela.eric@gmail.com

Received: 02-03-2019

Accepted: 05-06-2019 